\title{
TNFRSF1A Gene Product
}

National Cancer Institute

\section{Source}

National Cancer Institute. TNFRSF1A Gene Product. NCI Thesaurus. Code C147008.

A protein encoded by the TNFRSF1A gene. 